\title{
Developing A Sense Of Belonging: Findings From A Three Institution Study With Implications For BME Students And Staff Engagement.
}

\author{
Ronke Shoderu and Suzanne Kane \\ London Metropolitan University
}

\author{
Deborah Husbands \\ University of Westminster
}

\author{
Debbie Holly \\ Anglia Ruskin University
}

Acknowledgements to the wider project team:

Guglielmo Volpe, Queen Mary University, Helen Pokorny and David Chalcraft, University of Westminster, Linda Johnson, Myrtle Emmanuel, Yaz Djebbour and Andrew Halford, London Metropolitan University

\section{Abstract}

This article provides interim observations with reference to a three university study into the implications of students' sense of belonging in UK tertiary education. Descriptions related to sense of belonging were recorded via the biographic narrative interpretive method (BNIM) (Wengraf, 2007) and will be subject to further analysis via this method in later stages of the project. Initial findings include emergent themes and practice-based opportunities to increase students' sense of belonging.

\section{Introduction}

This article presents an evaluation of three student interviews, which represent one student from each of the universities engaged in the project. This is one part of the larger project, which includes the collection of questionnaire data from first year students at three London universities. The analysis of this survey data will be available in the later stages of the project. In addition to the collection of questionnaire data, in-depth interviews were carried out through the biographic narrative interpretive method (Wengraf, 2007).

The study investigates the experiences of new students entering university, and whether or not they recognise a level of sense of belonging to their chosen institution. While the concept of sense of belonging is not fully developed in this paper, in the literature (see Goodenow,1993) it is defined as the extent to which students feel personally accepted, respected, included and supported by others in the educational social environment. This research will address the gap in knowledge regarding students' sense of belonging in 
UK higher education. A specific objective of this project is to uncover and evaluate individual concepts of students' sense of belonging. To this end, rich descriptions, through the application of the biographic narrative interpretive method (BNIM) (Wengraf, 2007), were recorded and evaluated. The BNIM interview method allows interviewees to construct their own lived experience as free as possible from any researcherinfluenced bias, and offers rich description of the participant experience.

This project is informed by previous research, such as Tinto (1997) and Astin (1973), as well as a consideration of broader themes identified by other studies, such as individual culture and self-perception (Chow and Healy, 2008; de Beer, Smith and Jansen, 2009), university branding and the physical environment (Dixon and Durrhiem, 2004), induction events and transition (Vinson et al., 2010), teaching and group belonging (Hamilton, McFarland and Mirchandani, 2000; Levett-Jones and Lathlean, 2008).

\section{The interviews}

\section{Data collection}

The project team elected to use the BNIM interview method because it stimulates 'whole story' or 'long narrations', which allow interviewees to construct their own lived experience as free as possible from any researcher-influenced bias, and offer rich descriptions of the participant experience. It is a method of in-depth interviewing, which consists of an initial interview question, followed by additional prompting by reintroducing points from the narrative (known as: particular incident narratives). The research team endeavoured to record student narratives by listening to the lived-life experiences of students, without interruption where possible. Interviewees were informed that they would be asked one research question, and that they should simply talk about anything they considered relevant to the research question. They were also informed that the interviewer was not going to say anything, as they were only there to listen. The SQUIN (single question aimed at Inducing narrative) used for this project was:

"Can you tell me about the events in your life when you felt that you really belonged (and did not belong)? This might include university experiences, or not."

This question avoids limiting the spoken responses by allowing relationships to any part of the individual's narrative, not just that which is related or appears important in the university experience. While it was not possible to remain completely silent, the interviewers spoke as little as possible and only in an attempt to encourage the interviewees to continue their narratives. When the interviewees had found the natural end to their narrative the interviewers encouraged further remarks by highlighting a number of events or incidents (particular incident narratives), which had been stated. This often provided impetus for greater commentary.

All interview subjects self-selected for inclusion in the interview process. In advance of the interview, ethical protocol was explained to the subjects, including personal anonymity and confidentiality of the interviews. All subjects agreed that the research interviews could be used for the purposes of academic research.

\section{Data analysis}

Each interview was transcribed and printed. The eleven members of the project team split into three smaller groups to analyse the transcripts using text structure sequinization (Wengraf, 2007) and utilising the descriptive, argument, report, narrative, evaluation, (DARNE) framework. The groups discussed each section of the text and defined each part of the text as, descriptive, argument, reporting, narrative or evaluation. The groups then compared the results of these deliberations, and debated any points of difference, until there was complete agreement for each of the transcripts. The parts of the interviews agreed to be 'narrative' were taken forward for evaluation and comparison. Both the narratives and the delivery of the narratives are of interest here. 
This is a lengthy process, the analysis of one interview required the collaboration of eleven researchers for one day. However, these group analysis exercises do allow extensive discussion and debate towards final agreement via the DARNE typology. Additional stages of the interview analysis will be carried out later in the project.

Preliminary analysis of the three Interviews provided emergent themes, which relate to factors, which have emerged in prior literature (transition, university life/environment, and expectations/aspirations). The noted emergent themes can be seen to interweave through parts of all three interviews and are presented here under each theme. The emergent themes have related points of perspective, transition has 'past to present' perspectives, university life and experience has a 'present' perspective, and expectations and aspirations has 'present to future' perspectives.

All the interviewees are business students studying at London universities (two post and one pre 1992 institution). The interviewees were given pseudonyms; the boxer is UK born and educated, Rita is African born and UK educated, and Jean is Brazilian born and educated.

\section{Emergent theme: transition}

\section{Jean}

Jean's previous life experience was in her home country of Brazil, her recollections are of a place, which is friendly, warm, inclusive, welcoming and easy to make friends: "I think that everyone is completely different... I'm from Brazil where people are all friendly and welcoming and here I think people are very cold."

\section{Boxer}

The Boxer's home/family life recollections include tensions within his family and refers to them in a somewhat disconnected sense as "these people" and says: "...when I'm with my family I don't feel like I belong there because everyone's just screaming and they're crazy...I don't feel like l'm accepted there."

\section{Rita}

Rita's references to her family are positive, they accommodate her differing moods in a similar way that she is accommodating of their, sometimes, odd behaviour: "so it's great, you can just be yourself and they accept you... You wouldn't want to distance yourself saying this is not my family, you kind of want to be in it like yes, they're mine, they belong to me... and they're most like me..."

Cross comparison of the transition theme within the interviews:

All three interviews are dealing with the difficulties of transition to university life in different ways. Jean makes home life comparisons and considers her present environment as socially inferior. The boxer has a very different home life experience and describes a sense of alienation from his family. Rita is positive about her family and the support they give her.

The three interviewees had very different home life experiences, which underpin the way in which they endeavour to make sense of the transition period into university life. Jean attempts to mediate her disappointment within this early transition period by engaging with students she considers to share a similar history (Brazil and Spain). During this time of early transition, the boxer makes considerable effort to belong, in a way in which he feels he does not quite belong in his family environment. Rita positively identifies herself through her family background; she knows that her family will support her when she needs them. The interviewees have a range of past experiences to enable them, in differing ways, to navigate the transition period, which provides a foundation for future university life. 


\section{Emergent theme: university life/environment}

\section{Jean}

Jean comments that her fellow students are far too young and only think about their handbags, and that the university toilets are poor. She compares the shiny buildings from back home, and contrasts the old, historic 'London City' architecture: "...the building is very old, the class is very old, toilets very old. It was wow, this is London?" Her perspective of university life in London, reflects feelings of isolation: "...lots of black people talking to other black people and Muslim people talking to Muslims. And there was me, and you don't feel [part of] any group and you try to talk to someone, they look at you as if 'you don't belong to us'." A further narrative arises with regard to associating with students from other ethnic backgrounds, and she later reinforces the reliability of students from similar backgrounds when undertaking group work: "I found this Brazilian, there's the Spanish girl, they were more helpful. But...we had to do more than the others because you can't just rely on others sometimes."

Jean considers the university facilities as below par. She feels excluded by students of other ethnic origins, who group together. This increases her need for some point of belonging and is relieved to find other Brazilian and Spanish students. However, her distrust of students from other backgrounds remains.

\section{The boxer}

The boxer considers issues of class and ethnicity: "it's different for me" and "it really felt like yes, social class is showing here big time." He relates areas of the physical environment to cultural zones: "...there's a place called the Zone, that's where all the African people used to chill. And you go around here and this is the Quad, it's literally just Pakistan". He uses similar analogy for the university environment: "...you see the little Asian group in the front...then you've got all the Chinese at the front. You see them clusters." He seems to suggest that this is culturally exclusive territorial behaviour. He also feels a lack of connection with people from other departments because the buildings are far apart. In negotiating these perceived restricted areas, he attempts to create social spheres of belonging by interacting with other students: "...I walk around, hello, are you OK?" and "...meeting new people has made me realise that I can't be restricted, I can't put my guards up when I meet new people, you have to interact with them."

The boxer expresses tensions with fitting in among a diverse range of ethnic backgrounds and considers this to be a shared experience by other students. He presents a continuous awareness of cultural and class distinctions/boundaries. He also describes zones (in which he does not belong) where particular ethnic groups congregate. In addition to this, he feels disconnected from other university departments, but attempts to mediate this through an open, communicative approach when meeting new people.

\section{Rita}

Rita's initial impressions of university were disappointing: "when I came here initially I was a bit disappointed because it reminded me of my old college... So when I came here it was like I was taken back a bit, what I thought university was going to be like wasn't really like it. I thought shiny building, really impressive but it wasn't."

Rita's early impressions of the university buildings were poor, although she goes on to concede that its small size seemed to better facilitate student socialisation compared to a large university she had visited.

Cross comparison of the university life/environment theme within the interviews: 
Building a new life in the university environment appears to be problematic in a number of ways for our interviewees. Those who are not included in the dominant student groups see the groups as isolationist. The physical separation of department buildings and lack of interdisciplinary links also appear to cause feelings of detachment. However, Rita considers that her comparably smaller university provides a preferred social experience to larger institutions. All the interviewees have specific issues related to the practical factors of everyday, university life.

\section{Emergent theme: expectations/aspirations}

\section{Jean}

Jean draws a sharp contrast with the rigours of university study in Brazil: "yes, if you study full-time there, there's no way you can have a job at all, not even for a summer thing. Yes, because other than the 40 hours we do at university, we still have assignments and work placements that are compulsory that you need to do. So it's pretty much harder than here."

\section{Boxer}

The boxer's resilience and determination to succeed academically is reflected in the coping mechanisms he develops to provide a structure for study: "timetable plays a massive role for me" and this seems to help him to make sense of the perceived difficulties he experienced during the first semester.

\section{Rita}

Rita is very articulate and self-assured, with clear views on her academic journey: "well, I knew that whatever I wanted to do in the future, I expected to get paid a lot of money for it and I knew that without my degree, it would be very difficult to get there. And even though I wanted to do something in business, you can't really just start a business without knowing what to do, what a business is supposed to be like, structure, strategy. So that's why I came to uni for that."

Rita recounts her experiences of negotiating shifting landscapes resulting from the family having travelled extensively both internationally and within the UK, but this seems to result in increased self-confidence when accessing new and unfamiliar situations: "...I think l've moved four times now from the north (London) all the way gradually to the south (London)". She summarises for herself the essence of university: "... I think that's the most important thing about uni really, you don't just come up to be one thing, you can be whatever you want to be".

Cross comparison of the expectations/aspirations theme within the interviews:

Jean's expectations and aspirations do not match the reality of her UK experience. She expected to work hard and for long hours, but does not recognise this in the UK system. The boxer realises that he employs coping mechanisms and depends on a structured timetable. Rita's aspirations link to her life after the university experience. Her background of previously relocating to different areas of London, with her parents, aids her positive outlook and ability to cope with different situation.

\section{Discussion}

The interviewees link their past, present and future perspectives to make sense of particular associations with regard to; transition from home to university, experiences of university life and environment, and expectations they have of themselves and their aspirations. 
In regard to transition, Chow and Healey (2008) note that transition to a different social and cultural environment away from home has profound significance. Hausmann et al., (2009) suggest that social relationships with fellow students that are considered to be like-minded, related to individual sense of belonging. In addition, negative perceptions of the university as a learning environment, is not conducive to successful progression (de Beer et al., 2009).

Jean's early experience as an international student is that of moving to an unfriendly place. As a home student, the boxer has a very different background. He feels alienated at home and wants to fit into university life. Rita's family are a strong support network which she feels she can rely on. For international and UK students who are attempting to fit in, the university environment may be perceived as a daunting place, which does not provide the level of support required, and many students do not progress into the second year (Bennett and Kane, 2009).

Feeling the loss of home and family can relate to the loss of attachment to a community when entering higher education, this is not new and was remarked upon in the 1950's by Brownell (1959) and considered as a type of 'social suspension'.

In regard to university life and the university environment, the physical environment underpins our sense of self (Dixon, Durrheim, 2004), and, in Jean's and Rita's case, the environment does not meet with their expectations. Sturner (1972) defined the input of inhabitants (students and staff) as essential in the development of campus environments.

'The boxer', in relating his perception of some university areas as places for other races, suggests that he perceives himself to be in an environment dominated by groups to which he does not belong. The perception of not fitting-in has been related to students who are not part of the majority, in terms of race, and as such, may lack self-esteem (de Beer, Smith and Jansen, 2009). Hurtado et al., (2007) state the importance of 'cross-racial interactions' for higher sense of belonging on campus. However, Jean's strongest concern is the absence of people with which she feels able to bond. Dixon and Durrheim (2004) state the notion of belonging, as a 'group response' ethnic and racial factors relating to 'our space, their space' and the concept of 'insiders and outsiders', which the student relates when describing university locations where she does not naturally fit in (Ostrove, 2003).

Jean does not reflect well on her experience of campus life. This is problematic as the strongest influence on commitment to an institution comes from campus experiences (Strauss and Volkwein, 2004). Jean's expectations of university life did not include the possibility of peers who are less interested in academic achievement than her. The natural group formation of 'collective preferences' (Dixon, Durrheim, 2004) cannot accommodate students such as Jean, due to the limited number of peers, at the institution, from her cultural background. Experiencing lack of social integration is a factor that encourages students to leave (Mackie in Hassanien, Barber, 2007).

While cultural integration is a part of the university experience, it cannot develop over the length of a degree programme if students are not retained. Perhaps narratives such as that given by Jean can inform on issues of belonging for students from an international and cultural perspective.

In relation to expectations/aspirations, Jean's expectations and aspirations do not match the reality of her UK experience. She expected an academically challenging environment, but does not recognise this in her experience of the UK system. The boxer realises that he employs coping mechanisms and depends on a structured timetable, which allows him to manage his expectations and that which is expected of him. Rita's aspirations link to her life after the university experience. Her background of previously relocating to different areas of London with her parents, aids her positive outlook and ability to cope with different situations. 
The mismatch of expectations is detrimental to the progression of students and while actual changes that will provide an exact match may not be possible, such situations can be managed. Much can be achieved through the advice of personal academic advisers/supervisors. While Jean is perhaps seeking explanations, the boxer may simply require support, both of which are available through existing university systems in many cases. However, Rita's concerns have a future focus, which may be supported through the university careers service. While support systems are available to students, these narratives do not appear to include references to individual knowledge of such systems. Student expectations and aspirations may well be hindered by a simple lack of engagement with existing services, which they are either unaware of, or feel unable to access.

\section{Limitations of the study}

A number of limitations apply to the study. The initial stages of the BNIM method have been utilised, but further stages are yet to be completed. The data collection and analysis methods require extended periods of time to complete, which is the reason for constructing this as a paper which informs on the interim stage of the project. The research centres on the narratives of a small number of students. As such, the investigation considers the views of three students (one from each institution). Opportunities to collaborate through the analysis activities are limited due to time constraints. However, rich information is communicated via the narratives. Further research will include additional interviews in 2012 and more detailed qualitative and quantitative analysis of the survey and interview data.

\section{References}

Astin, A. W. (1973) Measurement and Determinants of the Outcomes of Higher Education. In: Solomon, L.C., and Taubman, P.J. (eds.) Does College Matter? Some Evidence of The Impacts of Higher Education. New York: Academic Press.

Bennett, R., Kane, S. (2010) Factors Associated with High First Year Undergraduate Retention Rates in Business Departments with Non-Traditional Student Intakes. The International Journal of Management Education, 8 (2), pp. 53-66.

Brownell, B. (1959) Higher Education and the Community: The Identification of Learning with Living. Journal of Higher Education, (9). pp. 469-480.

Chow, K., Healey, M. (2008) Place Attachment and Place Identity: First-Year Undergraduates Making the Transition from Home to University. Journal of Environmental Psychology. 28 (4), pp. 362-372.

de Beer, J., Smith, U., and Jansen, C. (2009) 'Situated' in a Separated Campus - Students' Sense of Belonging and Academic Performance: A Case Study of the Experiences of Students During a Higher Education Merger. Education as Change, 13 (1), pp. 167-194.

Dixon, J., Durrheim, K. (2004) Dislocating Identity: Desegregation and the Transformation of Place. Journal of Environmental Psychology. 24 (4), pp. 455-473.

Goodenow, C. (1993) The Psychological Sense of School Membership Among Adolescents: Scale Development and Educational Correlates. Psychology in the Schools, 30, pp. 79-90.

Hamilton, D., McFarland, D., and Mirchandani, D. (2000) A Decision Model for Integration Across the Business Curriculum in the $21^{\text {st }}$ Century. Journal of Management Education, 24 (1), pp. 102-126.

Hassanien, A., Barber, A. (2007) An Evaluation of Student Induction in Higher Education. International Journal of Management Education, 6 (3), pp. 35-43. 
Hurtado, S., Han, J., Saenz, V., Espinosa, L., Cabrera, N., and Cerna, O. (2007) Predicting Transition and Adjustment to College: Biomedical and Behavioral Science Aspirants' and Minority Students' First Year of College. Research in Higher Education, 48 (7), pp. 841-887.

Levett-Jones, T., Lathlean, J., Higgins, I., and McMillan, M. (2008) Staff-Student Relationships and their Impact on Nursing Students, Belongingness and Learning. Journal of Advanced Nursing, 65 (2), pp. 316-324.

Mackie, S.B. (2001) Jumping the Hurdles - Undergraduate Student Withdrawal Behaviour. In: Hassanien, A., and Barber, A. (2007) An Evaluation of Student Induction in Higher Education. International Journal of Management Education, 6 (3), pp. 35-43.

Ostrove, J. (2003) Belonging and Wanting: Meanings of Social Class Background for Women's Constructions of their College Experiences. Journal of Social Issues, 59 (4), pp. 771-784.

Strauss, L.C., and Volkwein, J.F. (2004) Predictors of Student Commitment at Two-Year and Four-Year Institutions. The Journal of Higher Education. 75 (2), pp. 203-227.

Sturner, W. (1972) Creating a Sense of Place on the College Campus. The Journal of Higher Education, 43 (2), pp. 97-109.

Tinto, V. (1997) Classrooms as Communities: Exploring the Educational Character of Student Persistence. The Journal of Higher Education, 68 (6), pp. 599-623.

Vinson, D., Nixon, S., Walsh, B., Walker, C., Mitchell, E., and Zaitseva, E. (2010) Investigating the Relationship Between Student Engagement and Transition. Active Learning in Higher Education, 11 (2), pp. 131-143.

Wengraf, T. 2007. Guide to BNIM. [Online]. Available from: tom@tomwengraf.com. 